\title{
Economic Analysis of the Production of Yellow Passion Fruit in an Area With Virose Incidence and Fertilized With NPK
}

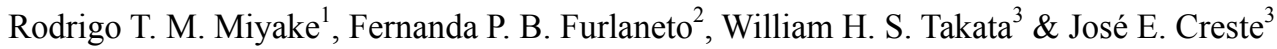 \\ ${ }^{1}$ Presidente Prudente, Brazil \\ ${ }^{2}$ Agency Paulista for Agribusiness Tecnology, Marília, Brazil \\ ${ }^{3}$ University of Western of São Paulo, Presidente Prudente, Brazil \\ Correspondence: Rodrigo T. M. Miyake, Presidente Prudente, Brazil. E-mail: rodrigomaruki@hotmail.com
}

Received: November 15, 2017

Accepted: February 25, $2018 \quad$ Online Published: April 15, 2018

doi:10.5539/jas.v10n5p303

URL: https://doi.org/10.5539/jas.v10n5p303

\begin{abstract}
The objective this work was to evaluate specific economic data of the production of yellow passion fruit under influence of different doses of NPK, in the form of $\mathrm{N}, \mathrm{P}_{2} \mathrm{O}_{5}$ and $\mathrm{K}_{2} \mathrm{O}$, in an area with incidence of virose in the city of Presidente Prudente, State of São Paulo. The following doses of NPK were evaluated: N (150 to $1200 \mathrm{~kg}$ $\left.\mathrm{ha}^{-1}\right), \mathrm{P}_{2} \mathrm{O}_{5}\left(200\right.$ to $\left.1600 \mathrm{~kg} \mathrm{ha}^{-1}\right)$ and $\mathrm{K}_{2} \mathrm{O}\left(100\right.$ to $\left.700 \mathrm{~kg} \mathrm{ha}^{-1}\right)$. Miyake et al. (2016) describe the methodology used in the formation of seedlings, fertilization and cultural treatments of passion fruit. The data used in the economic analysis were: productivity, commercial production, percentage and fruits of each commercial classification, cost of production and profitability of passion fruit. At the economical part, structures of the COE and TOC and four indicators of profitability were used. It was observed percentage difference in the operational cost of production of $4.0 \%$ between the highest and the lowest dose of $\mathrm{N}$, of $5.8 \%$ among doses of $\mathrm{P}_{2} \mathrm{O}_{5}$ and $1.7 \%$ among doses of $\mathrm{K}_{2} \mathrm{O}$. The total operating cost ranged from $\$ 29,119.77$ to $\$ 31,113.09$ per hectare. The profitability indicators were not favorable. It was concluded that the region of Presidente Prudente-SP, in areas with an incidence of viral infection, it is not recommended the plantation of passion fruits. However, at times with high selling price of fruit (average above R $\$ 1.95 \mathrm{~kg}^{-1}$ ), the dose of NPK indicated refers to $300 \mathrm{~kg}$ of N, $400 \mathrm{~kg}$ of $\mathrm{P}_{2} \mathrm{O}_{5}$ and $500 \mathrm{~kg}$ of $\mathrm{K}_{2} \mathrm{O} \mathrm{ha}^{-1}$.
\end{abstract}

Keywords: Passiflora edulis Sims, passion fruit, Cowpea aphid borne mosaic virus, production cost, economic indicator, profitability

\section{Introduction}

The Brazil is the main producer of passion fruit worldwide, being the fruit cultivated and marketed throughout the country (AGRINUAL, 2017). There has been an increasing occurrence of pathogens in the areas of agricultural production destined to the cultivation of passion fruits. The following viruses stand out (Passion fruit woodiness virus and Cowpea aphid borne mosaic virus), fungi (Fusarium solani and Fusarium oxysporum), bacteria (Xanthomonas axonopodis), nematodes (Meloidogyne spp.) and phytoplasms (Cavichioli et al., 2011; Cerqueira et al., 2014; Garcêz et al., 2015; Santos et al., 2017).

Among the pathogens, viruses, particularly the mosaic viruses of the fruits stands due to the severity that they cause to the culture, generating economical and social stalemates (Fischer et al., 2008; Ferreira, 2016). It is also highlighted, that there is no chemical method to control this disease.

Therefore, the mineral nutrition applied in an adequate way and quantity can contribute to the optimization of fruit productivity and quality in passion fruit cultivars (Sousa et al., 2014; Gonçalves, 2016). However, the quantities of $\mathrm{N}, \mathrm{P}$ and $\mathrm{K}$ recommended for the cultivation of passion fruit are very variable. In Brazil, it is recommended the implementation from 94 to $235 \mathrm{~kg} \mathrm{ha}^{-1}$ year $^{-1}, 30$ to $213 \mathrm{~kg} \mathrm{P}_{2} \mathrm{O}_{5} \mathrm{ha}^{-1}$ year ${ }^{-1}$ and 50 to $530 \mathrm{~kg}$ of $\mathrm{K}_{2} \mathrm{O} \mathrm{ha}^{-1}$ year $^{-1}$ (Ripardo, 2010). In addition, nutritional studies in areas with presence of virus are scarce, even more restricted when measuring the results of fertilization and production from the economic point of view.

In this sense, the objective was to evaluate specific economic data of the production of passion fruit under influence of different doses of $\mathrm{N}, \mathrm{P}_{2} \mathrm{O}_{5}$ and $\mathrm{K}_{2} \mathrm{O}$, in an area with incidence of virose aiming at better technical support of the production in this adverse condition. 


\section{Material and Methods}

\subsection{Characteristics of the Experimental Area}

The experiment was carried out in a commercial area located in the district of Montalvão, in the municipality of Presidente Prudente, region of Alta Sorocabana, SP. The experiment was performed from February 2013 to July 2014 (Table 1). It is characteristic of the region present $64 \%$ of agricultural properties with areas of up to 72 hectares (LUPA, 2015).

The experiment was carried out in an area where the planting of passion fruits occurs periodically. The interval between the last planting and the study corresponded to 3 months. The incidence of viral infection at the site was identified prior to the installation of the study.

The climate is Aw according to the Köppen classification, with tropical summer rainy season and a dry winter and the coldest month with an average temperature above $18{ }^{\circ} \mathrm{C}$. The driest month has rains lower than $60 \mathrm{~mm}$. The annual precipitation is approximately $1250 \mathrm{~mm}$ (CEPAGRI, 2017).

The predominant soil in the region is classified as dystrophic clayey soil, characterized by the form of soil relatively mild, still curled, by its nature not so cohesive in its surface and lower permeability in underground layers. It has a high susceptibility to erosion, which requires intensive practices to control erosion (IAC, 2016).

Table 1. Schedule of production of yellow passion fruit in the region of Presidente Prudente, crop 2013/2014

\begin{tabular}{ll}
\hline & Activity \\
\hline Crop 2013 & \\
$\begin{array}{l}\text { February-March } \\
\text { April-August }\end{array}$ & $\begin{array}{l}\text { Gathering fruits in the field to remove seeds } \\
\text { Setempber }\end{array}$ \\
\hline Crop 2014 & Field-planting \\
January & Start of flowering \\
February-July & Harvest \\
\hline
\end{tabular}

\subsection{Production of Seedlings of Yellow Passion Fruit}

The plant material was yellow passion fruit of variety 'Sul-Brazil Afruvec'. The seeds used in the production of seedlings were removed from healthy plants and highly productive commercial plantations in the region in February 2013. The seeds removed from fruits were placed in a plastic container for the seeds fermentation process, this technique consists of stirring the seeds to explode for a period of 72 hours. The greater the number of times that the seeds are stirred by day, the more easily to remove the layer that surrounds the aril of seeds, consequently the greater potential of germination of the seeds.

After the fermentation period o, the seeds were placed in Styrofoam trays of 200 divisions to seeding and, after germination, seedlings were transplanted into plastic bags black with holes, with capacity for 2 liters of substrate. The substrate used in plastic bags was the commercial substrate Bioplant ${ }^{\circledR}$ composed of pine bark, coconut fiber, vermiculite, carbonized rice and nutrients. The seedlings were developed to a size of approximately $2 \mathrm{~m}$ in height when they were planted in the field.

\subsection{Experimental Design}

The treatments were performed in factorial NPK fractioned $4^{3} \times 0.5$ split into two incomplete blocks with variations in the doses of $\mathrm{N}, \mathrm{P}_{2} \mathrm{O}_{5}$ and $\mathrm{K}_{2} \mathrm{O}$ (Table 2). The space among the plants was $2 \mathrm{~m}$ and $3 \mathrm{~m}$ between the lines $\left(1515\right.$ plants ha $\left.{ }^{-1}\right)$. The total area used of the experiment was $3801.6 \mathrm{~m}^{2}$. The variations used for the dose of $\mathrm{N}, \mathrm{P}_{2} \mathrm{O}_{5}$ and $\mathrm{K}_{2} \mathrm{O}$ were based upon the recommended dose in the Technical Bulletin 100 (Manure et al., 1997) for the cultivation of passion, as well as for other nutrients. The doses of $\mathrm{N}, \mathrm{P}_{2} \mathrm{O}_{5}$ and $\mathrm{K}_{2} \mathrm{O}$ recommended by Raij et al. (1997) correspond to 140,140 to $350 \mathrm{~kg} \mathrm{ha}^{-1}$, respectively. 
Table 2. Doses of $\mathrm{N}, \mathrm{P}_{2} \mathrm{O}_{5}$ and $\mathrm{K}_{2} \mathrm{O}\left(\mathrm{Kg} \mathrm{ha}^{-1}\right)$ application in experiment of yellow passion fruit, Presidente Prudente, crop 2013/2014

\begin{tabular}{llccl}
\hline Factor & \multicolumn{3}{c}{ Dose } \\
\hline $\mathrm{N}-(\mathrm{N})$ & 150 & 300 & 600 & 1200 \\
$\mathrm{P}-\left(\mathrm{P}_{2} \mathrm{O}_{5}\right)$ & 200 & 400 & 800 & 1600 \\
$\mathrm{~K}-\left(\mathrm{K}_{2} \mathrm{O}\right)$ & 100 & 300 & 500 & 700 \\
\hline
\end{tabular}

\subsection{Fertilization Management}

As sources of NPK, the following fertilizers were used: ammonium nitrate $(32 \% \mathrm{~N})$, triple superphosphate $(42 \%$ $\left.\mathrm{P}_{2} \mathrm{O}_{5}\right)$ and potassium chloride $\left(60 \%\right.$ of $\left.\mathrm{K}_{2} \mathrm{O}\right)$. The phosphate fertilization was applied in the furrow in a single dose in all treatments. Already the nitrogen $(\mathrm{N})$ and potassium fertilization $\left(\mathrm{K}_{2} \mathrm{O}\right)$ were provided in topdressing, divided monthly in 7 applications, from October/2013 to April/2014, and provided in accordance with the development of plants in order to optimize the use of nutrients.

\subsection{Characteristics Evaluated}

The data were collected from February 2014 to July 2014 in 180 to 360 DAS (days after planting). To estimate the operational cost of production, it was used the methodology of the Institute of Agricultural Economics (IAE), described in Martin et al. (1998). The price of the rate of the United States dollar (USD) was obtained in the price of official rate of Central Bank of Brazil (PTAX 800), measured in fractions and national currency units in Brazil, which was $\$ 3.16$ on 11/02/2015 ( Central Bank of Brazil, 2016).

The structures used in the production system were: Fertilization costs $(\mathrm{CF})=$ price and quantity of fertilizer applied at treatment; Effective operational cost $(\mathrm{EOC})=$ spending on labor, operations of machinery/equipment and materials consumed in the production process; Total operating costs (TOC) $=$ effective operational cost plus expenses with depreciation of machinery, social costs direct and indirect contribution of rural social security.

The activities studied included five steps: soil preparation, planting, formation of cultures, cultural practices and operations related to the harvest. Soil preparation operations, such as thinning, leveling, plowing, trenching, placement of pallets, liming (planting), planting (distribution of seedlings and replanting), handling of cultures (thinning and orientation of the plants, spraying for pest and disease control, preventing the proliferation of ants, the manual pollination and harvest were identical in all treatments.

In the manual operations, it was considered: (a) Labor: family farming, requiring two persons per hectare, (b) the equipment useful life: 10 years; (c)weight of fruits per box: $13 \mathrm{~kg}$; (d) the dollar exchange rate: USD 1.01. The prices of materials and labor followed the values prevailing in the city of Presidente Prudente, for the month of August 2017. The cost per hour and the depreciation of machinery and implements were based on the data available in the Series statistical information on agriculture (2016) and were adjusted through field research.

The total production corresponded to the sum of the productivity of plants for each treatment. It was also carried out an estimate of production per hectare according to the productivity per plant. The economic assessment also took into consideration: per treatment, yield (tons $\mathrm{ha}^{-1}$ ), commercial production (tons ha ${ }^{-1}$ ) and the percentage of fruits of each classification (\%). The sized 2 fruits were classified according to Ceagesp table and the sized 1 fruits were discarded. Table 3 shows the classification of the fruits according to the size and medium price of sale.

Table 3. Classification of fruits of yellow passion fruit, according to the gauge system, diameter of fruit (mm) and average price sale (USD kg ${ }^{-1}$ ), Presidente Prudente, crop 2013/2014

\begin{tabular}{llll}
\hline Classification & Gauge & Diameter fruit & Average Price sale \\
\hline $1^{\mathrm{a}}$ & 1 & $\leq 55$ & - \\
$2^{\mathrm{a}}$ & 2 & $\geq 55$ to 65 & 0.47 \\
$3^{\mathrm{a}}$ & 3 & $\geq 65$ to 75 & 0.57 \\
$4^{\mathrm{a}}$ & 4 & $\geq 75$ to 85 & 0.65 \\
Super & 5 & $>85$ & 0.74
\end{tabular}

Source: Ceagesp, 2017. 


\subsection{Statistical Analysis}

To calculate the economic analysis of collected data, the following formulas were used as described by Martin et al. (1998): The profitability indicators adopted were:

a) Gross Revenue (GR):

$$
\mathrm{GR}=\operatorname{Pr} \times \mathrm{Pu}
$$

where, $\mathrm{Pr}=$ production of activity per unit of area $\left(\mathrm{kg} / \mathrm{ha}^{-1}\right) . \mathrm{Pu}=$ unit price of the product of activity $\left(\mathrm{USD} / \mathrm{ha}^{-1}\right)$;

b) Operational Profit of Net Revenue (OP or NR):

$$
\mathrm{OP}=\mathrm{GR}-\mathrm{TOC}
$$

where, $\mathrm{TOC}=$ total operational cost of production $\left(\mathrm{USD} / \mathrm{ha}^{-1}\right)$;

c) Profitability Index (PI):

$$
\mathrm{PI}=(\mathrm{OP} / \mathrm{GR}) \times 100
$$

d) Balance Point (BP):

$$
\mathrm{BP}=\mathrm{TOC} / \mathrm{Pu}
$$

The data were analyzed by mathematical model:

$\mathrm{y}=\mathrm{B} 0+\mathrm{b} 11 \mathrm{~N}+\mathrm{b} 22 \mathrm{P}^{2}+\mathrm{B} 3 \mathrm{~K}+\mathrm{b} 33 \mathrm{~K}^{2}+\mathrm{b} 12 \mathrm{NP}+\mathrm{b} 13 \mathrm{Ni}+\mathrm{b} 23 \mathrm{PK}$

subjected to analysis of variance by Statistical Analysis System (SAS, 2010) and the variables whose response was significant at doses were analyzed by regression testing for the significance level of $p<0.05,<0.01 \%$.

\section{Results and Discussion}

In the present study, $100 \%$ of the plants showed visual symptoms characteristic of attack of viral infection of passion fruit after 120 days of installation of the experiment, which highlights the severity of the disease in the field. However, it was found that there was significant variation in productivity and in the production of marketable fruits in answers to the doses of $\mathrm{N}$. The doses of $\mathrm{K}_{2} \mathrm{O}$ influenced positively the quality of the fruits (Table 4).

The maximum productivity reached was 19.84 tons $\mathrm{ha}^{-1}$ of yellow passion fruit with the application of $300 \mathrm{~kg} \mathrm{~N}$ $\mathrm{ha}^{-1}$, being that the use of this dose about $83 \%$ of the fruits were within the commercial standard of sale (> size 2 ), which represented a yield of commercial fruits of 16.36 tons ha ${ }^{-1}$, even the variable being below the productive potential of culture regarding the areas without incidence of viral infections, it was superior to the average national production of 14 tons ha ${ }^{-1}$. The low production observed in the work is due to the rapid entry and spread of Passion fruit woodiness virus, the incidence of the disease in the experimental area was observed already at 60 days after planting in the field, i.e., the viral infection developed in the same period that the plants were in the plant formation stage. Miyake et al. (2016) obtained a medium productivity of 43 ton ha ${ }^{-1}$ in area without the presence of virus infection.

Cavichioli et al. (2011) observed in the city of Adamantina-SP the percentage of plants with symptoms of viral infection and the severity of symptoms in three rootstocks: Passiflora edulis, P. alata, P. gibertii and ungrafted plants. It was used as crown the yellow passion fruit (Passiflora edulis). It was noted that the plants with symptoms of viral infection occurred at 90 days after planting of seedlings in the field, reaching, at 180 days, $100 \%$ of plants with viral infection in P. alata and P. gibertii, and $97.5 \%$ in P. edulis and ungrafted plant.

This result for the parameter of productivity indicated that the dose of $200 \mathrm{~kg} \mathrm{ha}^{-1} \mathrm{P}_{2} \mathrm{O}_{5}$ and $100 \mathrm{~kg}$ of $\mathrm{K}_{2} \mathrm{O}$ were sufficient to meet the demand of the nutritional culture of passion fruit. Probably, the residues of fertilization existent of previous crops supplied the needs of plants, since the area was with cultivation of the crop for the fourth consecutive year.

The percentage of production of marketable fruits was superior in the treatment where it was used $700 \mathrm{~kg} \mathrm{ha}^{-1}$ of $\mathrm{K}_{2} \mathrm{O}$. There were no statistical variation in commercial production in the applied doses of $\mathrm{N}$ and $\mathrm{P}_{2} \mathrm{O}_{5}$ (Table 4). Even with no statistical difference, the nitrogen fertilization resulted in an increase in the number of fruits (from a dose of $300 \mathrm{~kg} \mathrm{ha}^{-1} \mathrm{~N}$ ). In addition, these fruits were classified in the size 4, i.e., fruit with high commercial value of sale (USD $0.64 \mathrm{Kg}$ ). 
Table 4. Productivity, total number of fruits, percentage of commercial fruit (PCF) and commercial fruit yield (CYF) of yellow passion fruit in response of doses of $\mathrm{N}, \mathrm{P}_{2} \mathrm{O}_{5}$ and $\mathrm{K}_{2} \mathrm{O}$, per ha ${ }^{-1}$, Presidente Prudente, crop $2013 / 2014$

\begin{tabular}{|c|c|c|c|c|c|c|}
\hline Factor & Dose & Productivit & & $\mathrm{N}^{\mathrm{o}}$ fruit & PCF & CFY \\
\hline & & $\mathrm{kg}$ plant $^{-1}$ & ton $\mathrm{ha}^{-1}$ & Total & $\%$ & ton $\mathrm{ha}^{-1}$ \\
\hline \multirow[t]{4}{*}{$\mathrm{N}$} & 150 & 8.90 & 13.48 & 205 & $0, .83$ & 11.33 \\
\hline & 300 & 13.09 & 19.84 & 308 & 0.82 & 16.36 \\
\hline & 600 & 12.46 & 18.88 & 305 & 0.81 & 15.54 \\
\hline & 1200 & 11.51 & 17.44 & 307 & 0.77 & 13.36 \\
\hline Effect & & $\mathrm{Q}^{* *}$ & $\mathrm{Q}^{* *}$ & NS & NS & $\mathrm{Q}^{* *}$ \\
\hline \multirow[t]{4}{*}{$\mathrm{P}_{2} \mathrm{O}_{5}$} & 200 & 10.75 & 16.29 & 260 & 0.83 & 13.52 \\
\hline & 400 & 12.16 & 18.43 & 298 & 0.81 & 15.08 \\
\hline & 800 & 11.41 & 17.29 & 292 & 0.77 & 13.28 \\
\hline & 1600 & 11.63 & 17.63 & 275 & 0.82 & 14.72 \\
\hline Effect & & NS & NS & NS & NS & NS \\
\hline \multirow[t]{4}{*}{$\mathrm{K}_{2} \mathrm{O}$} & 100 & 10.40 & 15.77 & 269 & 0.75 & 11.89 \\
\hline & 300 & 12.31 & 18.66 & 305 & 0.81 & 15.08 \\
\hline & 500 & 12.40 & 18.79 & 291 & 0.83 & 15.72 \\
\hline & 700 & 10.84 & 16.43 & 259 & 0.84 & 13.90 \\
\hline Effect & & NS & NS & NS & $\mathrm{L}^{* *}$ & $\mathrm{Q}^{* *}$ \\
\hline CV $(\%)$ & & 27.65 & 27.89 & 27.38 & 5.41 & 29.89 \\
\hline
\end{tabular}

Note. L: linear; Q: quadratic; NS: non significative:* significative $(\mathrm{p}<0.05)$; ${ }^{* *}$ significative: $(\mathrm{p}<0.01)$.

In the work developed by Sampaio et al. (2008) was analyzed the quality of the fruits and the productivity of yellow passion fruit, in two annual cycles with seedlings of selection Afruvec. The first symptoms of the virus of passionfruit woodiness in the leaves were detected when the plants were already formed and in full flowering. The total production of the first year was 27.12 ton ha $^{-1}$, preventing the highest production of fruits with sizes 2 and 3. During the harvest period, the fruit industry type showed steady growth and above $10 \%$ of the fruits harvested from $40^{\text {th }}$ harvest, reaching $33 \%$ at the end of the season and surpassing the $22 \%$ of the previous harvest. The progressive increase of these types of fruits is due to the onset of the virus infection.

Gioria (2000) found that, the earlier the plants are contaminated, the greater is the economic impairment of the activity. Losses both in number and weight reached $80 \%$ when the seedlings became infected at the age of 2 months. Whereas seedlings that became infected at 4 and 6 months, the losses were 74 and $44 \%$, respectively. These results stress out the importance of the deployment of protected greenhouses in system of seedlings production of yellow passion fruit in different regions of Brazil.

Mello (2009) evaluated the productivity and the reaction of 12 genotypes of passion fruits to viral infection of passionfruit woodiness, in Federal District. It was identified that all the varieties were mildly susceptible. Rubi Gigante stood out with the lowest averages of severity and incidence of virus in leaf (56\%), while the lowest incidence in plant (79\%) was verified with the genotype MAR\#19.

The difference in production and fruit quality (size) of passion fruit based on this study and in other studies (Sampaio et al., 2008; Gioria, 2000; Mello, 2009) depends on some factors like: the genotype used, realization of cultural treatments (nitrogen, windbreak, plant treatment, among others), but the main factor is the age of incidence of viral infection in plants in the field. It is known that the more previously there is the attack of the virus in the passion in the field, the greater its severity will be and the lower the production of the plant, as a result, the greater will be the reduction of economic profitability of the culture.

In the fertilizations with the variation of $\mathrm{N}$ and $\mathrm{K}_{2} \mathrm{O}$ it is noticed the difference in fruits size. It was not identified any significant difference in fruit size 1,2, 3 and 5, in doses of $\mathrm{N}$. Whereas, the fruits of size 4 were bigger with use of the dose of $150 \mathrm{~kg} \mathrm{ha}^{-1}$. In different doses of $\mathrm{K}_{2} \mathrm{O}$, it was identified that the variation in sizes 2 (100 kg $\left.\mathrm{ha}^{-1}\right)$ and $4\left(500 \mathrm{~kg} \mathrm{ha}^{-1}\right)$, as shown in Table 5.

The average total production of fruits size 1 in all treatments was approximately $1.4 \%$, fruits of size $2,16.9 \%$, fruits of size $3,38.5 \%$; fruits of sizes $4,38.2 \%$ of fruits of size $5,4.6 \%$. 
Table 5. Percentage of classification of fruits of yellow passion fruit in response of doses de $\mathrm{N}_{2} \mathrm{P}_{2} \mathrm{O}_{5}$ and $\mathrm{K}_{2} \mathrm{O}$, Presidente Prudente, crop 2013/2014

\begin{tabular}{|c|c|c|c|c|c|c|}
\hline \multirow{3}{*}{ Factor } & \multirow{3}{*}{ Dose } & \multicolumn{5}{|c|}{ Classification (\%) } \\
\hline & & Gauge 1 & Gauge 2 & Gauge 3 & Gauge 4 & Gauge 5 \\
\hline & & $<55 \mathrm{~mm}$ & $55-65 \mathrm{~mm}$ & $65-75 \mathrm{~mm}$ & $75-85 \mathrm{~mm}$ & $>85 \mathrm{~mm}$ \\
\hline \multirow[t]{4}{*}{$\mathrm{N}$} & 150 & 1.35 & 14.79 & 37.54 & 41.56 & 4.77 \\
\hline & 300 & 1.41 & 16.13 & 37.62 & 39.93 & 4.89 \\
\hline & 600 & 1.06 & 16.90 & 38.63 & 38.17 & 5.22 \\
\hline & 1200 & 2.09 & 20.04 & 40.60 & 33.48 & 3.77 \\
\hline Effect & & NS & NS & NS & Q & NS \\
\hline \multirow[t]{4}{*}{$\mathrm{P}_{2} \mathrm{O}_{5}$} & 200 & 1.73 & 14.93 & 39.42 & 37.31 & 6.61 \\
\hline & 400 & 1.37 & 16.49 & 36.14 & 42.33 & 3.64 \\
\hline & 800 & 1.73 & 20.63 & 37.26 & 37.15 & 3.21 \\
\hline & 1600 & 1.08 & 15.81 & 41.57 & 36.34 & 5.18 \\
\hline Effect & & NS & $\mathrm{Q}^{*}$ & NS & NS & NS \\
\hline \multirow[t]{4}{*}{$\mathrm{K}_{2} \mathrm{O}$} & 100 & 1.81 & 22.38 & 40.36 & 32.61 & 2.84 \\
\hline & 300 & 1.58 & 16.75 & 38.58 & 37.71 & 5.36 \\
\hline & 500 & 1.31 & 15.23 & 35.02 & 43.11 & 5.30 \\
\hline & 700 & 1.21 & 13.49 & 40.04 & 39.69 & 5.14 \\
\hline Effect & & NS & $\mathrm{L}^{* *}$ & NS & $\mathrm{Q}^{* *}$ & NS \\
\hline $\mathrm{CV}(\%)$ & & 27.39 & 18.90 & 8.81 & 11.78 & 41.07 \\
\hline
\end{tabular}

Note. L: linear; Q: quadratic; NS: non significative: * significative $(\mathrm{p}<0.05)$; ${ }^{*}$ significative $(\mathrm{p}<0.01)$.

The economic analysis pointed that there was percentage difference in the operational cost of production of $4.7 \%$ between the highest and the lowest dose of $\mathrm{N}$, of $6.8 \%$ among doses of $\mathrm{P}_{2} \mathrm{O}_{5}$ and $2.5 \%$ among doses of $\mathrm{K}_{2} \mathrm{O}$. Whereas, the largest difference in cost of production among the doses used and the recommended dose was $4.0 \%$, 5.8 and $1.7 \%$ for the different doses of NPK, per treatment, respectively (Table 6). The total operational cost ranged between USD 9,215.11 to USD 9,845.91 per hectare.

It was noticed that the production cost was increasing in virtue of the doses used of fertilizer, however, this additional economic cost did not reflect increased productivity per area. It was found, however, that there was variation in the commercial quantity of production. Thus, it was essential to analyze the profitability of the crop taking into account the cost of production in relation to the final value of the sale of the product generated in each treatment.

It is still highlighted, that Furlaneto et al. (2011) identified for the cultivation of passion fruit, in 2010/2011 harvest, in the region of Marília, São Paulo State, a total cost of production of R \$37,751.67 (\$23,743.19) per hectare or R\$ 1.89 (\$1.19) per kilogram of fruit. The indicators of profitability were unfavorable to the production system analyzed, due mainly to the high price of inputs and inadequate practices for disease control. The authors emphasized the need for adequate techniques relating to the management of plant health and nutritional status of culture for the reduction of total cost of production in order to make the activity profitable. Situations were ratified in the present study.

According to the Yearbook of Brazilian Agriculture (2017), in the Central West region of São Paulo, year 2016, the total operational cost for production of passion fruit irrigated land was $\$ 9,906.96$ per hectare per year, taking into account a yield of 25 tones per hectare and the density of 952 plants per hectare. It is emphasized that in this locality there is intense involvement of the plantation related to phytosanitary problems. 
Table 6. Cost of fertilization ( $\mathrm{CF} \mathrm{ha} \mathrm{h}^{-1}$ ), total operational cost per hectare (TOC $\mathrm{ha}^{-1}$ ), effective operational cost per treatment (EOC), percentage between the total operational cost per treatment the standard dose and the dose application in yellow passion fruit obtained in the experiment with doses of $\mathrm{N}_{2} \mathrm{P}_{2} \mathrm{O}_{5}$ and $\mathrm{K}_{2} \mathrm{O}$, held in Presidente Prudente, crop 2013/2014

\begin{tabular}{|c|c|c|c|c|c|}
\hline Factor & Dose & $\mathrm{CF}$ & TOC & EOC & $\begin{array}{l}\text { Percentage between the TOC of } \\
\text { standard dose and the test dose }\end{array}$ \\
\hline & & $\mathrm{USD} \mathrm{ha}^{-1}$ & $\mathrm{USD} \mathrm{ha}^{-1}$ & USD treat $^{-1}$ & $\%$ treat $^{-1}$ \\
\hline \multirow[t]{4}{*}{$\mathrm{N}$} & 150 & $414.59 \mathrm{c}$ & $9,242.64 \mathrm{~b}$ & $439.20 \mathrm{~b}$ & $99 \mathrm{~b}$ \\
\hline & 300 & $486.21 \mathrm{c}$ & $9,305.23 \mathrm{~b}$ & $442.18 \mathrm{~b}$ & $100 \mathrm{~b}$ \\
\hline & 600 & $629.47 \mathrm{~b}$ & $9,430.40 \mathrm{~b}$ & $448.13 \mathrm{~b}$ & $101 \mathrm{~b}$ \\
\hline & 1.200 & $916.93 \mathrm{a}$ & $9,680.75 \mathrm{a}$ & $460.02 \mathrm{a}$ & $104 \mathrm{a}$ \\
\hline \multirow[t]{4}{*}{$\mathrm{P}_{2} \mathrm{O}_{5}$} & 200 & $375.64 \mathrm{~d}$ & $9,215.11 \mathrm{~b}$ & $437.90 \mathrm{c}$ & $99 \mathrm{~b}$ \\
\hline & 400 & $476.77 \mathrm{c}$ & $9,305.23 \mathrm{~b}$ & $442.18 \mathrm{bc}$ & $100 \mathrm{~b}$ \\
\hline & 800 & $679.03 \mathrm{~b}$ & $9,485.45 \mathrm{~b}$ & $450.75 \mathrm{~b}$ & $102 \mathrm{~b}$ \\
\hline & 1.600 & $1,083.54 \mathrm{a}$ & $9,845.91$ a & $467.87 \mathrm{a}$ & $106 \mathrm{a}$ \\
\hline \multirow[t]{4}{*}{$\mathrm{K}_{2} \mathrm{O}$} & 100 & $391.24 \mathrm{~d}$ & $9,225.59 \mathrm{~b}$ & $438.40 \mathrm{a}$ & $99 \mathrm{~b}$ \\
\hline & 300 & $481.49 \mathrm{c}$ & $9,305.23 \mathrm{~b}$ & $442.18 \mathrm{a}$ & $100 \mathrm{~b}$ \\
\hline & 500 & $571.75 \mathrm{~b}$ & $9,384.86 \mathrm{~b}$ & $445.96 \mathrm{a}$ & $101 \mathrm{ab}$ \\
\hline & 700 & $662.00 \mathrm{a}$ & $9,464.49 \mathrm{a}$ & $449.75 \mathrm{a}$ & $102 \mathrm{a}$ \\
\hline
\end{tabular}

Note. The means followed by the same letter column non-statistical difference $(\mathrm{P}<0.05)$, according to SAS test $(\mathrm{n}=4)$. The standard dose of $\mathrm{N}, \mathrm{P}_{2} \mathrm{O}_{5}$ and $\mathrm{K}_{2} \mathrm{O}$ recommended by Bulletin 100 to yellow passion fruit corresponding of 140,140 and $350 \mathrm{~kg} \mathrm{ha}^{-1}$, respectively.

To estimate the profitability of the fertilizations evaluated, it was discarded the production of fruits size 1 . It was calculated the selling of fruits sizes 2 to 5 . Due to the low productivity (mean $14.156 \mathrm{t} \mathrm{ha}^{-1}$ ), the economic results were unfavorable. The best revenue, despite of negative, occurred in the combination of the following dose of fertilization: $300 \mathrm{~kg}$ of $\mathrm{N}, 400 \mathrm{~kg}$ of $\mathrm{P}_{2} \mathrm{O}_{5}$ and $500 \mathrm{~kg}$ of $\mathrm{K}_{2} \mathrm{O} \mathrm{ha}^{-1}$. The same result occurred in the profitability index of the culture. For this combination of fertilization with NPK, the minimum selling price of passion fruit needed to be USD 0.61 per $\mathrm{kg}$ of fruit (Table 7).

Table 7. Gross revenue (GR Fr) from sale of fruit, according to the caliber, total gross revenues (Total GR), net revenues (NR), profitability index (PI) and balancing point (BP) for yellow passion fruit obtained in the experiment with doses of N, $\mathrm{P}_{2} \mathrm{O}_{5}$ and $\mathrm{K}_{2} \mathrm{O}$ held in Presidente Prudente, crop 2013/14

\begin{tabular}{|c|c|c|c|c|c|c|c|c|c|}
\hline \multirow{2}{*}{ Factor } & \multirow{2}{*}{ Dose } & \multicolumn{4}{|c|}{ GR Fr } & \multirow{2}{*}{ Total GR } & \multirow{2}{*}{ NR } & \multirow{2}{*}{ PI } & \multirow{2}{*}{$\mathrm{BP}$} \\
\hline & & Cal. 2 & Cal. 3 & Cal. 4 & Cal. 5 & & & & \\
\hline & & ------. & ----------- & USD treat & $\mathrm{nt}^{-1}-\cdots$ & ------------- & ------------ & $\mathrm{JSD} \mathrm{Kg}^{-1}$ & ------- \\
\hline \multirow[t]{4}{*}{$\mathrm{N}$} & 150 & $1.08 \mathrm{a}$ & $14.36 \mathrm{~b}$ & $41.57 \mathrm{c}$ & $52.39 \mathrm{c}$ & $109.41 \mathrm{~d}$ & $-329.79 a$ & -301.40 & $0.81 \mathrm{a}$ \\
\hline & 300 & $1.62 \mathrm{a}$ & $22.62 \mathrm{a}$ & $60.15 \mathrm{a}$ & $72.69 \mathrm{a}$ & $157.10 \mathrm{a}$ & $-285.07 b$ & -181.46 & $0.56 \mathrm{c}$ \\
\hline & 600 & $1.16 \mathrm{a}$ & $22.51 \mathrm{a}$ & $58.67 \mathrm{a}$ & $66.00 \mathrm{~b}$ & $148.36 \mathrm{~b}$ & $-299.77 b$ & -202.05 & $0.60 \mathrm{c}$ \\
\hline & 1.200 & $1.97 \mathrm{a}$ & $22.94 \mathrm{a}$ & $53.01 \mathrm{~b}$ & $49.77 \mathrm{c}$ & $127.71 \mathrm{c}$ & $-332.10 \mathrm{a}$ & -260.19 & $0.72 b$ \\
\hline \multirow[t]{4}{*}{$\mathrm{P}_{2} \mathrm{O}_{5}$} & 200 & $1.65 \mathrm{a}$ & $17.30 \mathrm{~b}$ & $52.09 \mathrm{~b}$ & $56.13 \mathrm{~b}$ & $127.18 \mathrm{~b}$ & $-310.71 b$ & -244.31 & $0.68 \mathrm{~b}$ \\
\hline & 400 & $1.45 \mathrm{a}$ & $21.31 \mathrm{a}$ & $53.27 \mathrm{~b}$ & $71.03 \mathrm{a}$ & $147.08 \mathrm{a}$ & $-295.10 b$ & -200.64 & $0.61 \mathrm{c}$ \\
\hline & 800 & $1.62 \mathrm{a}$ & $23.48 \mathrm{a}$ & $48.36 \mathrm{c}$ & $54.90 \mathrm{~b}$ & $128.37 \mathrm{~b}$ & $-322.37 \mathrm{a}$ & -251.12 & $0.71 \mathrm{a}$ \\
\hline & 1.600 & $1.12 \mathrm{a}$ & $19.94 \mathrm{~b}$ & $59.81 \mathrm{a}$ & $59.52 \mathrm{~b}$ & $140.41 \mathrm{a}$ & $-327.46 \mathrm{a}$ & -233.22 & $0.66 \mathrm{~b}$ \\
\hline \multirow[t]{4}{*}{$\mathrm{K}_{2} \mathrm{O}$} & 100 & $1.52 \mathrm{a}$ & $22.81 \mathrm{a}$ & $46.90 \mathrm{~b}$ & $43.14 \mathrm{c}$ & $114.38 \mathrm{~d}$ & $-324.01 \mathrm{a}$ & -283.27 & $0.77 \mathrm{a}$ \\
\hline & 300 & $1.68 \mathrm{a}$ & $21.65 \mathrm{a}$ & $56.86 \mathrm{a}$ & $63.28 \mathrm{~b}$ & $143.48 \mathrm{~b}$ & $-298.69 b$ & -208.17 & $0.61 \mathrm{c}$ \\
\hline & 500 & $1.45 \mathrm{a}$ & $20.52 \mathrm{a}$ & $53.81 \mathrm{a}$ & $75.41 \mathrm{a}$ & $151.20 \mathrm{a}$ & $-294.76 b$ & -194.95 & $0.59 \mathrm{c}$ \\
\hline & 700 & $1.18 \mathrm{a}$ & $16.07 \mathrm{~b}$ & $54.40 \mathrm{a}$ & $61.39 \mathrm{~b}$ & $133.05 \mathrm{c}$ & $-316.69 a$ & -238.02 & $0.68 \mathrm{~b}$ \\
\hline
\end{tabular}

Note. The means followed by the same letter column non-statistical difference $(\mathrm{P}<0.05)$, according to SAS test $(\mathrm{n}=4)$. The standard dose of $\mathrm{N}, \mathrm{P}_{2} \mathrm{O}_{5}$ and $\mathrm{K}_{2} \mathrm{O}$ recommended by Bulletin 100 to yellow passion fruit corresponding of 140,140 and $350 \mathrm{~kg} \mathrm{ha}^{-1}$, respectively. 
It is stressed out that Miyake et al. (2016) analyzed economically different types of nutritional management in yellow passion fruit, with variations of $\mathrm{N}$ doses $\left(150,300,600\right.$ and $\left.1200 \mathrm{~kg} \mathrm{ha}^{-1}\right), \mathrm{P}_{2} \mathrm{O}_{5}(200,400,800$ and 1600 $\left.\mathrm{kg} \mathrm{ha}^{-1}\right)$ and $\mathrm{K}_{2} \mathrm{O}\left(100,300,500\right.$ and $\left.700 \mathrm{~kg} \mathrm{ha}^{-1}\right)$ in the municipality of Presidente Prudente, region of Alta Sorocabana. They concluded that there was no significant variation in fruit yield as a function of doses of NPK. However, there was differentiation in the quality of the fruits The operating profit and the profitability index were more satisfactory on the application of $300 \mathrm{~kg}$ of N, $400 \mathrm{~kg}$ of $\mathrm{P}_{2} \mathrm{O}_{5}$ and $500 \mathrm{~kg}$ of $\mathrm{K}_{2} \mathrm{O}$, per hectare. For this combination of fertilization, the minimum selling price of passion fruit needed to be USD 0.26 per $\mathrm{kg}$ of fruit (Table 7).

In another study, Lima et al. (2009) analyzed the profitability of passion fruit in six production Brazilian Centers (Benevides-PA, Araguari-MG, Itapuranga-GO, Integrated Development Region of the Federal District and surrounding areas, Bom Jesus da Lapa-BA and Vera Cruz-SP) and observed that the culture of yellow passion fruit is economically viable at the centers when productivity is greater than 19 tones per hectare/year. However, due to the sharp increase in the price of inputs and the price of a kilo of fruit in the last 05 years (average of $\left.\mathrm{R} \$ 1.61 \mathrm{~kg}^{-1}\right)$, it is necessary to increase the productivity per hectare, as well as minimize the cost of production and cause the activity to be sustainable economically.

\section{Conclusion}

In the city of Presidente Prudente, region of Alta Sorocabana, SP, under conditions of soil, management and climate evaluated and in lands with an incidence of viral infection, it is not recommended the planting of passion fruits due to the unfavorable profitability to agribusiness.

However, at times with high selling price of fruit (average above $\mathrm{R} \$ 0.61 \mathrm{~kg}^{-1}$ ), the dose of $\mathrm{N}, \mathrm{P}_{2} \mathrm{O}_{5}, \mathrm{~K}_{2} \mathrm{O}$ indicated refers to $300 \mathrm{~kg}$ of N, $400 \mathrm{~kg}$ of $\mathrm{P}_{2} \mathrm{O}_{5}$ and $500 \mathrm{~kg}$ of $\mathrm{K}_{2} \mathrm{O}$ per hectare.

It is therefore recommended to add more $160 \mathrm{~kg}$ of N, $160 \mathrm{~kg}$ of $\mathrm{P}_{2} \mathrm{O}_{5}$ and $150 \mathrm{~kg}$ of $\mathrm{K}_{2} \mathrm{O}$ per hectare in relation to the indication of Technical Bulletin 100, for the culture of yellow passion fruit in order to obtain the economic optimization of entrepreneurial activity.

\section{References}

AGRINUAL. (2017). Anuário da agricultura brasileira (22th ed.). São Paulo, SP: Agra FNP Pesquisas.

Cavichioli, J. C., Corrêa, L. S., Narita, N., \& Kasai, F. S. (2011). Incidência and severidade do vírus do endurecimento dos frutos em maracujazeiros enxertados em pé-franco. Revista Brasileira de Fruticultura, 33(Special), 411-414. https://doi.org/10.1590/S0100-29452011000500053

CEPAGRI. (2017). Clima dos municipios paulistas. Retrieved from http://www.cpa.unicamp.br/outras-informa ções/clima-dos-municípios

Cerqueira, C. B. M., Conceição, L. D. H. C. S., Souza, A. P., \& Corrêa, R. X. (2014). A history of passion fruit woodiness disease with emphasis on the current situation in Brazil and prospects for Brazilian passion fruit cultivation. European Journal Plant Pathology, 139, 261-270. https://doi.org/10.1007/s10658-014-0391-z

Ferreira, C. C. (2016). Desempenho agronômico and reação de genótipos de maracujazeiro às doenças fúngicas, bacterioses and virose do endurecimento do fruto sob condições de campo and casa de vegetação. Retrieved from http://repositorio.unb.br/handle/10482/22453

Fischer, I. H., \& Resende, J. A. M. (2008). Diseases of passion flower (Passiflora spp.). Pest Technology, 2, $1-19$.

Furlaneto, F. P. B., Martins, A. N., Esperancini, M. S. T., Vidal, A. A., \& Okamoto, F. (2011). Custo de produção do maracujá amarelo (Passiflora edulis). Revista Brasileira de Fruticultura, 33(Special), 441-446. https://doi.org/10.1590/S0100-29452011000500058

Garcêz, R. M., Chaves, A. L. R., Eiras, M., Meletti, L. M. M., Azevedo Filho, J. A., Silva, L. A., \& Colariccio, A. (2015). Survey of aphid population in a yellow passion fruit crop and its relationship on the spread Cowpea aphid borne mosaic virus in a subtropical region of Brazil. Springer Plus, 4, 1-12. https://doi.org/ 10.1186/s40064-015-1263-5

Gioria, R., Bosquê, G. G., Rezende, J. A. M., Amorim, L., \& Kitajima, E. W. (2000). Incidência de viroses de maracujazeiro na Alta Paulista-SP and danos causados pelo "Passion fruit woodiness vírus". Fitopatologia Brasileira, 25, 182-189.

Gonçalves, Z. S. (2016). Reação de maracujazeiros (Passiflora spp.) à virose do endurecimento dos frutos (Unpublished master's thesis, Universidade Federal do Recôncavo da Bahia, Cruz das Almas, Brasil). 
IAC (Instituto Agronômico de Campinas). (2016). Classificação dos solos do Estado de São Paulo. Retrieved from http://www.iac.sp.gov.br/solossp

Lima, M. M., Azevedo, D. B., \& Santos Junior, S. (2009). Comparativo da rentabilidade da produção de maracujá em seis polos no Brasil. Revista Inovação, Gestão and Produção, 5, 54-69.

LUPA (Levantamento Censitário das Unidades de Produção Agropecuária). (2015). Censo Agropecuário. Retrieved from http://www.agricultura.sp.gov.br/censo-agropecuario-paulista

Martin, N. B., Serra, R., Oliveira, M. D. M., Ângelo, J. A., \& Okawa, H. (1998). Sistema integrado de custos agropecuários-CUSTAGRI. Informações Econômicas, 28, 7-28.

Mello, R. M. (2009). Desempenho agronômico and reação à virose do endurecimento dos Frutos em genótipos de maracujazeiro-azedo, cultivados no Distrito Federal (Master's thesis, Universidade de Brasília, Brasília, Brazil). Retrieved from http://http://repositorio.unb.br/bitstream/10482/4781/3/2008_ThalesEduardoG Maia.pdf

Miyake, R. T. M., Furlaneto, F. P. B., Narita, N., Takata, W. H. S., \& Creste, J. E. (2016). Economic evaluation of different types of nutritional management in yellow passion fruit vines (Passiflora edulis Sims.). Australian Journal of Crop Science, 11, 1572-1577. https://doi.org/10.21475/ajcs.2016.10.11.PNE190

Raij, B. V., Cantarella, H., Quaggio, J. A., \& Furlani, A. M. C. (1997). Boletim técnico 100: Recomendações de adubação and calagem para o Estado de São Paulo. Campinas, SP: Instituto Agronômico, Fundação IAC.

Ripardo, A K. S. (2010). Doses de NPK no desenvolvimento, produtividade and qualidade de frutos do maracujazeiro "Roxinho do Kênia" (Doctoral dissertation, Universidade Estadual Paulista, Botucatu, Brazil). Retrieved from https://repositorio.unesp.br/handle/11449/93506

Sampaio, A. C., Scudeller, N., Fumis, T. F., Almeida, A. M., Pinotti, R. N., Garcia, M. J. M., \& Pallamin, M. L. (2008). Manejo cultural do maracujazeiro-amarelo em ciclo anual visando à convivência com o vírus do endurecimento dos frutos: Um estudo de caso. Revista Brasileira de Fruticultura, 30, 2,343-347. https://doi.org/10.1590/S0100-29452008000200013

Santos, C. L., Viana, A. P., Freitas, M. S. M., Carvalho, A. J. C., \& Rodrigues, D. L. (2017). Relationship between yield and fruit quality of passion fruit $\mathrm{C}_{03}$ progenies under different nutritional levels. Revista Brasileira de Fruticultura, 39, 691-701. https://doi.org/10.1590/0100-29452017691

SAS (Statistical Analysis System Institute). (2010). SAS/STAT 9.2 user's guide (2th ed.). SAS Institute Inc: North Carolina.

Série Informações Estatísticas da Agricultura. (2016). Anuário de informações estatísticas da agricultura. São Paulo, SP: Instituto de Economia Agrícola.

Sousa, V. F., Folegatti, M. V., Frizzone, J. A., Corrêa, R. A. L., \& Eloi, W. M. (2003). Produtividade do maracujazeiro-amarelo sob diferentes níveis de irrigação and doses de potássio via fertirrigação. Pesquisa Agropecuária Brasileira, 38, 497-504. https://doi.org/10.1590/S0100-204X2003000400008

\section{Copyrights}

Copyright for this article is retained by the author(s), with first publication rights granted to the journal.

This is an open-access article distributed under the terms and conditions of the Creative Commons Attribution license (http://creativecommons.org/licenses/by/4.0/). 